\title{
NINETEENTH CENTURY CAPE TOWN VISITORS TO THE POSTOJNA CAVE, SLOVENIA
}

\author{
Stephen A. CRAVEN ${ }^{1}$ \\ UDC 551.44(497.4)(091)
}

\section{INTRODUCTION}

For three centuries the spectacular Postojna Cave in Slovenia has attracted tourists (Habe 1986). Fortunately for the historian the early visitors were required to sign the visitors' books which have survived the twentieth century turbulence in the Balkans, and which are kept at the Karst Research Institute in Postojna. Those visitors who wrote about the Cave have been discussed by Trevor Shaw (2008). Most of the visitors came from Europe, but also from the Americas and from Asia. There were very few visitors from Africa for the very good reason that the mailships serving Cape Town did not call at Trieste - the major port for the Austro-Hungarian empire (Harris \& Ingpen 1994). Also there were very few people with the necessary financial and temporal resources.

This paper records seven known, and three or four unknown, visitors from Cape Town in the nineteenth century.

\section{OCTOBER 1858 \\ Mr. \& Mrs. Gerhard Myburgh, Cape of Good Hope}

Gerhard Myburgh was born on 14 February 1830 in Rondebosch, lived at Orange Grove, Breda Street, Gardens, and died there on 16 December 1886 (Cape Archives A). He married Jacomina Aletta Fleck on 4 March 1857 in Cape Town. His widow died on 7 February 1894 at Blueberg House, Blaauwberg (Cape Archives B). He was a partner in the family "importers and general merchant" business at 23 St. George's Street, a director of the Equitable Marine and Fire Assurance Company, of the Mutual Assurance Society and of the South African Association. His late father's first liquidation and distribution account, filed on 23 March 1862, confirms that the family business profits were more than adequate to send the young Gerhard and Jacomina to Europe (Cape Archives C). For sixteen years he was Consul-General for the Netherlands, and for Denmark (Cape Argus 1886).

\section{OCTOBER 1863}

W. Hertzog. 4 person(s) Cape of Good Hope. Cape City South A(frica)

Willem (alias William) Frederick Hertzog, born 15 May 1841 (De Villiers \& Pama 1981a) was a wealthy Cape gentleman farmer. He owned the adjacent farms Bergvliet, Kreupelbosch, Sweet Valley (Cape Archives D) and Longueville (since renamed Meadowridge), now middle class suburbs of Cape Town (Howes 2007). There is no record of the names of his companions. He died unmarried, intestate and without issue on 3 September 1902 in a Hamburg, Germany, hospital having become ill while a passenger on the "Hamburg steamship Hertzog" (Cape Archives E). The distant relatives in England, Sophia Wilhelmina Jonosina Purcell and Anna Margaretha Jeffcoat née Hertzog, litigated for sixteen years before the estate was eventually liquidated (Cape Archives F).

\section{NOVEMBER 1871}

\section{J.C. Molteno Cape of Good Hope \\ Caroline Molteno Cape of Good Hope \\ Elizabeth Molteno Cape of Good Hope}

John Charles Molteno was a wealthy businessman and sheep farmer near Beaufort West who was elected Member for that town in 1854, and who was elected the first Prime Minister of the Cape Colony in December 1872. In 1871 he and his two eldest daughters visited Postojna Cave during their tour of Europe. His brief mention of the Cave, and its indirect influence on the development of railways at the Cape, have been discussed elsewhere (Craven 2006).

\footnotetext{
17 Amhurst Avenue, Newlands 7700, South Africa, e-mail: sacraven@mweb.co.za

Received/Prejeto: 13.11.2009
} 


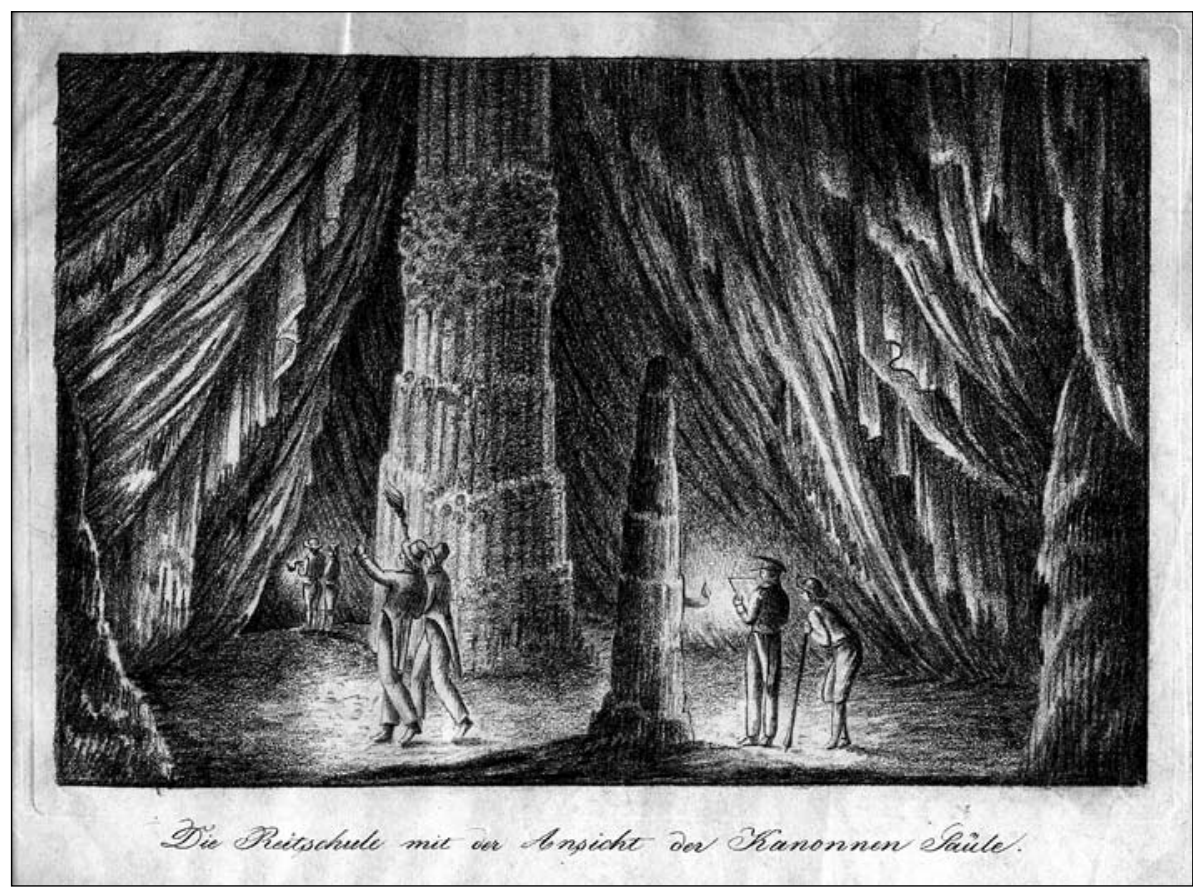

Fig. 1: A. Schaffenrath's motif of Postojnska Jama (1820-30); (Karst Research Institute library, Postojna).

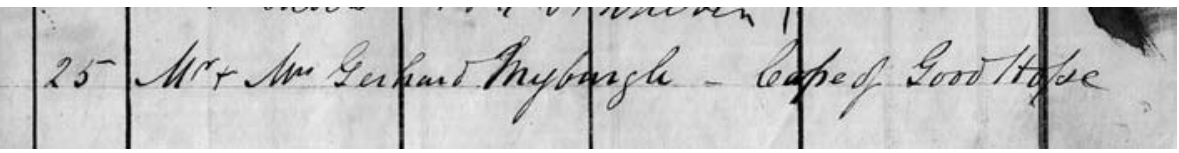

Fig. 2: Signature of Gerhard Myburgh and wife (Karst Research Institute library, Postojna).

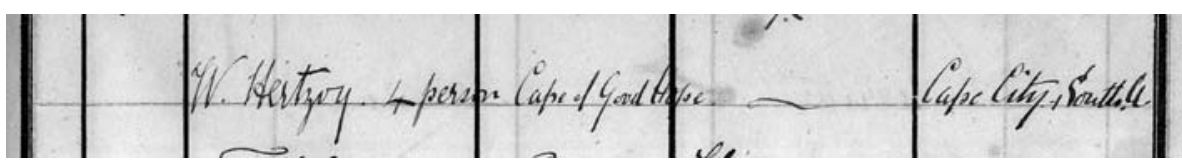

Fig. 3: Signature of Willem Hertzog (Karst Research Institute library, Postojna).

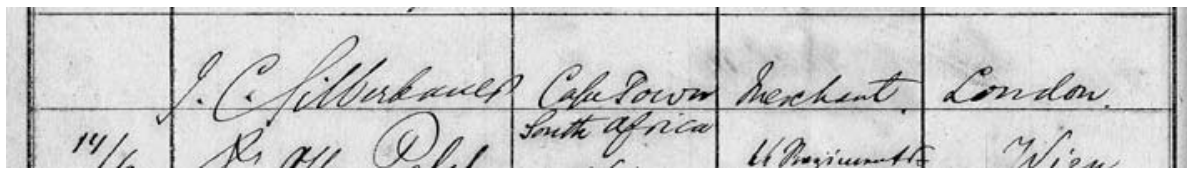

Fig. 5: Signature of Johan Conrad Silberbauer (Karst Research Institute library, Postojna).

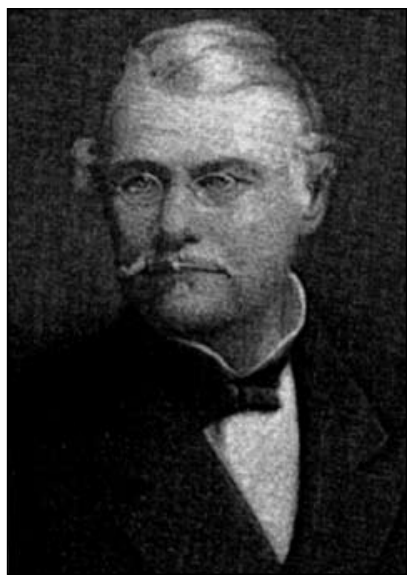

Fig. 4: Johan Conrad Silberbauer, taken from Liefeldt \& Robertson 1986.

mous firm of Cape Town lawyers (Liefeldt \& Robertson 1986). He was born on 14 March 1826, married Adamina Gabrielina Helena de Smidt on 19 June 1851 (De Villiers \& Pama 1981b) or 1852 , and died suddenly of acute peritonitis at his residence, Bloemendal House, Mowbray, on 28 April 1897. All his relatives were out of Town.

Silberbauer was one of the early Cape Town City Wardmasters in 1854 (The Cape of Good Hope Almanack 1854) and 1855 (The Cape of Good Hope Almanack 1855) for Ward No. 3, and for Ward No. 36 in 1856 (The Cape of Good Hope Almanack 1856). He was elected Member of the House of Assembly for Caledon 1859

\section{JUNE 1889}

J.C. Silberbauer native Cape Town, merchant London

Johan Conrad Silberbauer was a Cape Town corn merchant who is best known for his second son, Conrad Christian, who in 1885 founded the well-known epony-
- 1868 (Kilpin 1938). He was also a director of the Cape Commercial Bank and an auditor for the Union Mining Company (Solomon 1854). His obituary writer confirmed that he had travelled extensively in Europe, and in Palestine, Egypt and America (Cape Argus 1897). 


\section{ACKNOWLEDGMENTS}

Mrs. Maja Kranjc and Dr. Trevor Shaw are thanked for the photocopies of the relevant pages of the visitors' books. André Myburgh Esq. of Fribourg, Switzerland, kindly supplied information about Gerhard Myburgh.
Nick Muller Esq., senior partner of Messrs. Cliffe Dekker Hofmeyr, identified the Silberbauer who visited the Cave.

\section{REFERENCES}

Cape Archives (A) MOOC 6/9/240 109.

Cape Archives (B) MOOC 6/9/325 317.

Cape Archives (C) MOOC 13/1/201 10.

Cape Archives (D) MOOC 13/1/1169 48.

Cape Archives (E) MOOC 6/9/458 3113.

Cape Archives (F) MOOC 13/1/3225 256.

Cape Argus 17 Dec. 1886 p. 2.

Cape Argus 29 Apr. 1897 pp. 2 \& 5.

Craven, S.A., 2006: Postojnska Jama in Slovenia, the Südbahn and the visit of John Charles Molteno: their influence on the development of railways in South Africa. Acta Carsologica, 35, 1, 159 - 162.

De Villiers, C.C. \& C. Pama, 1981a: Genealogies of old South African families 1.- Balkema, pp. 911, Cape Town:

De Villers, C.C. \& C. Pama, 1981b: Genealogies of old South African Families 2.- Balkema, pp. 884, Cape Town.

Habe, F., 1986: The Postojna Caves and other Tourist Caves in Slovenia.- In: Šajn, S. (ed.) 100 Let turističnega društva Postojna, Postojna. TD Postojna, 6-9, Postojna.

Harris, C.J. \& B.D. Ingpen, 1994: Mailships of the UnionCastle Line.- Fernwood Press pp. 23, Vlaeberg.
Howes, S., 2007: Sweet Valley we are here.- Sweet Valley Primary School, pp. 13, Cape Town.

Kilpin, R., 1938: The Parliament of the Cape.- Longmans, Green \& Co., pp. 155, London.

Liefeldt, E.R. \& M. Robertson, 1986: A Century of Practice Silberbauers 1885 - 1985- Silberbauers, pp. 106, Cape Town.

Shaw, T.R., 2008: Foreign Travellers in the Slovene Karst 1486 - 1900.- ZRC Publishing, pp. 338, Ljubljana.

Solomon, S., 1854: The Cape of Good Hope Diary and Bill-Due Book for the year 1855.- Saul Solomon, pp. 27, Cape Town.

The Cape of Good Hope Almanack and Annual Register for 1854.- Van der Sandt de Villiers, pp. 133, Cape Town.

The Cape of Good Hope Almanack and Annual Register for 1856.- Van der Sandt de Villiers, pp. 133, Cape Town.- Van der Sandt de Villiers, pp. 135, Cape Town.

The Cape of Good Hope Almanack and Annual Register for 1855.- Van der Sandt de Villiers, pp. 143, Cape Town. 